\title{
História das emoções, epistolografia e homossexualidades no Brasil: "(...) vocês falam pela minha garganta muda"
}

\author{
History of emotions, epistolography and homosexualities in Bra- \\ zil: "(...) you speak for my throat mudet"
}

Paulo Roberto Souto Maior*

Resumo: Este artigo objetiva discutir a temática do assumir-se homossexual nas cartas de leitor presentes no jornal Lampião da Esquina (1978-1981), distribuído nacionalmente durante sua produção. Dentre os vários temas que constituíram essa documentação epistolar, elejo a preocupação com a visibilidade pela sua frequência tanto na seção, como nas demais matérias veiculadas no periódico. Portanto, escrevo uma história das emoções em torno do binômio calar ou falar a homossexualidade no Brasil entre as décadas de 1970-80.

Palavras-chave: História das emoções; homossexualidades; epistolografia; jornal lampião da esquina

\footnotetext{
* Graduado em História pela Universidade Federal de Campina Grande. Mestre em História pela Universidade Federal de Pernambuco. É doutorando em História na Universidade Federal de Santa Catarina (UFSC) e pesquisador do Laboratório de Estudos em Gênero e História da mesma instituição. É bolsista de doutorado do CNPq. E-mail: paulosoutom@gmail.com .
} 


\begin{abstract}
This article aims to discuss the issue of taking up gay in the player cards present in the newspaper Lampião da Esquina (1978-1981), distributed nationally during production. Among the various topics that constituted this epistolary documentation elect concern for visibility by its frequency both in the section, as other articles published in the journal. Therefore, I write a story of emotions surrounding the binomial silent or speak homosexuality in Brazil between the decades of 1970-80.
\end{abstract}

Keywords: History of emotions; homosexualities; epistolography; newspapers lampião da esquina

Fazia muito frio. Na Campina Grande de 1978, o inverno chegou mais cedo, mais forte. O relógio ainda não marcava dezoito horas, mas já havia anoitecido. M.C.L., morador(a) daquela cidade conhecida no interior do Nordeste, caminhou na calçada da Praça da Bandeira. No seu rosto, um olhar de coragem mesclava-se a um suspiro de receio. Determinado(a) e atento(a), caminhava firme em direção à Livraria Livro 7 para adquirir o novo número do Lampião da Esquina. Saiu do estabelecimento, observou o comércio fechando. Sentiu uma noite fria e pouco iluminada pelas nuvens pesadas embaçando o céu. Caminhou em direção ao seu fusca vermelho, modelo 1976. Lá mesmo se deleitou na leitura.

Extasiado(a) com o que tinha em mãos, com o conteúdo daquelas páginas, escreveu ao jornal, implorando: "digam que não estou sonhando, confirmem que Lampião chegará a Campina Grande todos os meses, garantam". ${ }^{1}$ A escolha dessa carta pelos organizadores da edição aponta para a voz de um sujeito do qual sabemos apenas as iniciais, permanecendo oculta sua identidade; sua transcrição explicita o desejo de ler o jornal. A localização aponta para uma cidade de interior, o que é sugestivo, afinal, há homossexuais em todos os lugares, e onde os houvesse, o Lampião se esforçava para chegar.

Mas de que se tratava o Lampião da Esquina? Foi um jornal surgido em abril de 1978, escrita por e destinada em grande medida ao público homossexual, a qual integrava parte da imprensa alternativa que emergiu no país, sobretudo após a abertura "lenta e gradual" proposta em 1975 pelo então presidente Ernesto Geisel.

O periódico circulou ininterruptamente até junho de 1981, quando, de 
repente, findou a publicação. Há várias hipóteses para o seu término, mas elas parecem se encontrar numa dupla justificativa: dificuldades econômicas e disputas internas entre o corpo editorial. O corpo editorial do Lampião era constituído, inclusive, por jornalista, artistas, intelectuais, professores universitários. Na edição de número zero, há menção aos nomes de: Peter Fry, Jean-Claude Bernadet, João Antônio Mascarenhas, Darcy Penteado, Aguinaldo Silva, João Silvério Trevisan, Adão Costa, Clóvis Marques, Francisco Bittencourt, Gasparino Damata, Antônio Chrysóstomo.

A sede do jornal ficava no Rio de Janeiro e era comandada por Aguinaldo Silva e a sucursal de São Paulo por Trevisan. É oportuno destacar as seções do jornal, geralmente com a notável indicação do que agradava a leitura do público. Já no seu primeiro número, entre as dezesseis páginas, encontrava-se: Cartas na mesa, espaço de publicação das correspondências de leitores; Tendências, geralmente com informações sobre filmes, peças de teatro, lançamento de obras literárias, espaço para trechos de livros ou poemas; e Esquina, seção com assuntos destinados ao comportamento homossexual.

À medida que o jornal tornava-se conhecido entre leitores e assinantes, não apenas nos grandes centros, mas também nos mais distantes rincões do Brasil, outras seções foram surgindo. É o caso de Bixórdia, que trazia histórias protagonizadas por homossexuais. O jornal explicava aos leitores que o título da seção tinha o objetivo de abrir espaço para a "representação do que é livre, autopermitido" 2 porque no seu conteúdo "se misturam viados, bichas, perobos, tias, sobrinhas, primas, entendidos, gueis, transadores, mariconas, paneleiros, frescos, frutas e xinbugos". ${ }^{3}$

Outros jornais, cujo objetivo era uma empreitada menos ambiciosa, precederam o Lampião da Esquina. Certamente, um dos mais conhecidos tenha sido $O$ Snob, publicação caseira, produzida no Rio de Janeiro entre 1963-1969, que trazia notícias sobre concursos de misses e espaços de sociabilidades. $\mathrm{O}$ modelo de relação entre homens difundido pela publicação dava importância ao bicha $\mathrm{x}$ bofe; ${ }^{4}$ o primeiro aparecia como passivo na relação sexual, o que é penetrado, ocupando na cama, ou nos terrenos baldios, nos banheiros públicos, nos prédios em construção, nas ruas desertas, função semelhante a da mulher. O bofe, por sua vez, era o ativo, quem penetrava, geralmente não se reconhecia como homossexual por executar a função do homem na relação sexual.

A singularidade do Lampião pode ser apontada em algumas questões: a sua distribuição em âmbito nacional, com uma tiragem de quinze mil exemplares; os temas que se propôs discutir, envolvendo-se na trama política que lhe foi contemporânea e tratando de questões de negros, mulheres, indígenas, meio ambiente, anistia política; o incômodo que causou no meio policial da época, quando alguns de seus jornalistas foram obrigados a prestar depoimento sobre a publicação; o movimento homossexual brasileiro que divulgava parte de sua embrionária trajetória no periódico e a maneira como abordava temas 
homossexuais, barrando estereótipos e preconceitos, oferecendo um espaço discursivo inédito para a elaboração de subjetividades homossexuais.

Talvez por esse conjunto de razões, receber o Lampião da Esquina era uma emoção inusitada. Em texto recentemente publicado, o professor Jorge Caê Rodrigues confidencia:

Apesar do passar do tempo, ainda é forte na minha memória a lembrança do dia no qual recebi o envelope pardo contendo o número zero do jornal Lampião da Esquina. Foi uma mistura de medo, ansiedade e curiosidade. Eu conhecia algumas pessoas envolvidas no lançamento do jornal, daí meu nome ter ido parar na mala direta dos produtores que estavam escolhendo as pessoas que iriam receber o número experimental. Lembro-me que corri para o quarto, tentando disfarçar a ansiedade e ocultar o medo de ser pego com um jornal gay. O que seria um jornal gay? Que tipo de matérias eu encontraria? Homens nus?

O jornal foi lido ao longo de semanas. Não podia lê-lo depois do almoço ou no fim da tarde: o ato de lê-lo era algo secreto e quase sagrado. Depois comprei o número 1 , o número 2 e assim por diante. Mas durante todo esse tempo o jornal era lido escondido. Não havia fotos de sexo, nem de homens nus, mas eu pensava: "O que diriam meus pais se encontrassem o jornal? Será que o fato de ter um jornal gay na minha casa indicaria a minha orientação sexual ou seria visto como mais um jornal dos muitos que eu comprava? ${ }^{5}$

Muitos anos se passaram e Rodrigues se tornou conhecido por estudar impressos destinados a homossexuais no Brasil. O que fica do seu depoimento é a novidade do jornal em si e todos os seus conteúdos, o medo de fazer a leitura; assinar o periódico equivalia a arriscar-se. E era com esse risco que vários homossexuais rumavam para bancas do país em buscar de ler sobre o material veiculado no jornal, reconhecer nele um pouco sobre os seus desejos e, depois, quem sabe, relatar suas dores, temores, alegrias para as Cartas na mesa.

Essas cartas acompanharam toda a existência do jornal. Durante boa parte da trajetória do Lampião, elas ocuparam cerca de duas páginas da publicação, número sugestivo, sobretudo porque, no começo, o mensário circulava com 16 páginas; na edição $04,{ }^{6}$ passou a contar com 20 páginas, indício do sucesso editorial. Porém, quando se aproximava do fim do periódico, a partir de dezembro de 1980, edição 31, a seção passou a ter direito a apenas uma página, o que se dava na medida em que crescia o número de anúncios publicitários no Lampião, possivelmente presentes por causa da crise financeira intensificada no periódico no seu último ano de publicação. Mas, antes de adentrar no conteúdo 
dessas cartas, gostaria de situar alguns trabalhos sobre o jornal em questão, objetivando apresentar em que a minha proposta difere.

Até onde avancei, apenas um trabalho estudou a seção de cartas de leitores no Lampião. Ela foi alvo de reflexões na dissertação de Márcio Leopoldo Bandeira $^{7}$ A leitura que o autor faz tem dois fins: a análise da construção das subjetividades dos indivíduos no ato de escrever cartas e da atitude de se reconhecer homossexuais através da escrita das correspondências enviadas ao jornal.

Bandeira não abdica do seu lugar de historiador: ele contextualiza, situa, demarca. Aí a fonte aparece associada também aos ideais jovens da contracultura norte-americana e europeia com variadas formas de tratar o erotismo, os "valores morais" e os comportamentos vigentes. Mais do que isso: para Bandeira, o Lampião da Esquina insere o homossexual numa relação igualitária junto a outros discriminados. A análise da seção de cartas do jornal sugere que havia pessoas apoiando a afirmação homossexual em diversos lugares do país.

Outras pesquisas tocam en passant no Lampião. Uma delas é a tese de doutorado do brasilianista norte-americano James Green, que se tornou o livro Além do Carnaval: a homossexualidade masculina no Brasil do século XX, de 1889-1985. ${ }^{8}$ Defendida em 1996, na Universidade da Califórnia, foi traduzida e lançada no Brasil em 2000. Sua pesquisa tornou-se referência para os trabalhos sobre gênero e sexualidade no país.

Green aborda a conjuntura que levou ao surgimento do movimento homossexual na década de 1970. Para ele, foi entre 1969 e 1980 que ocorreram as condições históricas e sociais para o florescimento de certo tipo de uma imprensa gay. ${ }^{9}$ Além disso, esses pequenos jornais eram influenciados por algumas publicações editadas nos Estados Unidos. Desde os anos 1960, aponta Green, essa influência da cultura homossexual já se fazia presente no Brasil por meio de um jornal gay de curta duração intitulado Gente Gay. O Lampião da esquina seria uma publicação inspirada nos periódicos norte-americanos voltados para o público homossexual, especialmente o jornal Gay Sunshine.

No entanto, o autor sustenta que a preocupação do grupo que criou o Lampião era sair do gueto, romper com estereótipos de que o homossexual deveria viver escondido e cercado de poucos amigos também do meio. Devido a isso, o periódico passou a influenciar organizações de homossexuais. O destaque conferido por Green aos discursos do Lampião deve-se à inovação no modo de escrever e ver as relações entre pessoas do mesmo sexo, rompendo com os textos médico-legais, tão característicos da primeira metade do século XX.

O estudo de Facchini, Sopa de Letrinhas ${ }^{10}$, sobre a dinâmica do movimento homossexual valendo-se de processos de elaboração de identidade coletivas, critica o trabalho de Green, pelo fato de ele, de acordo com as palavras da socióloga, ter adotado uma perspectiva "evolucionista" para explicar o início 
do movimento gay, ou seja, o fato de ter havido vários pequenos eventos, a contar com a publicação de jornais e espaços de sociabilidade, que permitiram condições amadurecidas para o movimento. Facchini trabalha com o Lampião da Esquina visando mostrar como o vínculo do grupo contribuiu para dinamizar a rede social do movimento homossexual brasileiro, ressaltando a sua importância na criação de identidades.

$\mathrm{Na}$ dissertação de autoria de Almerindo Cardoso Simões Júnior, ${ }^{11}$ por meio de uma considerável leitura do conceito de memória em Pollak e de lugar de memória em Pierre Nora, defende como o jornal foi responsável por uma "(re)afirmação homossexual", tentando circunscrever os processos de construção dessa identidade. Ao tomar a fonte como lugar de memória, opera uma divisão dos anos de vida do jornal, acoplando-os em certas temáticas: 1978, a afirmação de uma identidade homossexual; 1979, o homossexual político; 1980, o movimento homossexual organizado.

Há outro trabalho sobre o Lampião: Reinventando o sonho: história oral de vida política e homossexualidade no Brasil contemporâneo ${ }^{12}$, dissertação elaborada por Cláudio Roberto da Silva. O projeto de Silva debruça-se quase exclusivamente sobre os relatos orais, entrevistando membros do corpo editorial do Lampião da Esquina, a fim de historicizar o movimento político desencadeado por essa publicação e a constituição do movimento homossexual no país. Confere destaque à constituição identitária do movimento homossexual que teria se dado, especialmente, devido ao autoexílio de pessoas que moraram no exterior e se tornaram locutores importantes das mudanças da época, influenciados, segundo a visão do autor, pela abertura política do regime militar e por movimentos como a contracultura.

A fonte usada neste artigo permite ler aspectos de sociabilidades em algumas cidades do Nordeste, o que fez o artigo Trilhas urbanas, armadilhas humanas: a construção de territórios de prazer e de dor na vivência da homossexualidade masculina no Nordeste brasileiro dos anos setenta e oitenta. ${ }^{13}$ Valendo-se da História Cultural, os autores, Durval Muniz de Albuquerque Júnior e Rodrigo Ceballos, recorrem a periódicos, como o Lampião da Esquina, e ao Jornal do Comércio, de Pernambuco, a fim de cartografar como vinham se constituindo espaços de lazer e diversão para culturas homossexuais em algumas cidades do Nordeste, sem deixar de reconhecer a existência de ambientes onde a violência contra os homossexuais se fazia presente.

Dentre os locais de sociabilidade, os autores enumeram praias, becos, bares, discotecas e banheiros públicos, evidenciando-se, de fato, a conquista de vários ambientes, o desejo de ser aceito em locais de sociabilidades não somente gays. Daí o problema formulado pelos pesquisadores: muitas das propagandas e informações sobre os espaços de sociabilidade se referiam ao Nordeste, região construída historicamente como machista e conservadora em seus costumes. Assim, recorrem ao Lampião da Esquina para, no terreno 
das sociabilidades, desconstruir o argumento de um Nordeste como espaço apenas para machos.

Parece, portanto, que há uma lacuna em estudar as sensibilidades dos homossexuais diante do assumir-se recorrendo à epistolografia presente no jornal.

Narrar os problemas de se aceitar como homossexual era, sobretudo, mostrar para um outro, o destinatário, particular ou coletivo, um sentimento: medo. Esse sentimento situava uma preocupação de uma maioria, conforme se vê na seção Cartas na Mesa. A edição de dezembro de 1979 traz duas cartas sobre o assunto:

Essas qualidades me afetam muito, porque durante quase toda minha vida fui uma pessoa muito insegura, como se o fato de ser homossexual fosse a pior desgraça do mundo. Eu me dividia muito e vivia muito angustiada, até que resolvi procurar uma psicoterapia que tem me ajudado muito. Após tantos anos de sofrimento, já consigo curtir mais a vida, já consegui fazer amigos homossexuais. Já não sofro tanto e tenho uma imensa vontade de escrever e criar coisas. ${ }^{14}$

Mais:

Querido amigo Lampião: escrevo esta porque estou me sentindo muito só. Não importa se choveu e se agora está fazendo sol, se o que sinto é tempestade. Estou com vontade de escrever, talvez assim eu me sinta melhor. Desde que conheci esse jornal tem sido uma ansiedade esperar por esse número. De ver o carinho e a seriedade com que vocês tratam todos os problemas, de ler as cartas, de saber que não sou só eu. Vivo praticamente em casa, com meu violão, discos, livros e a televisão. Se não fosse a faculdade não sei se suportaria essa solidão. Às vezes chego a sentir que solidão é meu feminino singular e vai ser sempre assim. Fico pensando como é que posso ser e estar só numa cidade como essa (...).

É um sufoco, sabe? Tenho vontade de largar tudo e sumir mas sei que não vale a pena, não tenho condições financeiras para assumir meus atos e ser dona do meu nariz. Enquanto isso estou armazenando forças, tomando conhecimento através de vocês, que são uns amores. Meus queridos não deixem que nenhuma força cale as nossas vozes através desse jornal. Sabe, já estou me sentindo melhor e por isso 
morrendo de vergonha por contar o que sinto, mas só desse jeito é que eu poderia desabafar meu enrustimento, essa timidez e essa vergonha de tudo. ${ }^{15}$

Possivelmente a escrita das cartas acima tenha se dado em uma solidão semelhante ao modo como parte da sociedade dos anos 70 também percebia os homossexuais, como indivíduos solitários, mas também pervertidos. Nesta descrição percebe-se as razões do assumir-se colocados por Lampião. Assim, temos depoimentos que permitem conexões com a confissão da sexualidade, porque se aproximam dos conjuntos de práticas discursivas construídas na cultura ocidental para extrair dos sujeitos a verdade sobre o seu sexo. ${ }^{16}$

O tempo que se encerra nessa edição, a década de 1970, deveria trazer maneiras de vencer a tristeza, é o que se vê nas cartas. O escrever sobre si para o jornal vem preencher uma lacuna, a falta de um receptor. O constante monólogo travado por homossexuais nessas cartas, caracterizado pela situação de estigma diante da sociedade, podia se tornar um diálogo aberto ao grande público. Cartas como essas, refletindo sentimentos e emoções, ao serem colocadas no Lampião pareciam deixar uma mensagem aos leitores: vocês não estão sozinhos.

Tanto na carta de Penny quanto na de R. Andrade percebe-se a necessidade da amizade, função que foi preenchida com o Lampião. O jornal funcionou como um outro disposto a escutar, um outro que ouve e torna possível a fala, o desabafo, a confissão.

A amizade entre o leitor e o jornal, estabelecida através das cartas, possibilitava compreender sentimentos dos homossexuais brasileiros no fim da ditadura militar e o modo como esses sujeitos foram afetados por um presente opressor, no qual restava sonhar ou projetar linhas de fuga, criando outros espaços, outras possibilidades de resistir a condições de preconceito e exclusão presentes no dia a dia. Talvez restasse ainda a esperança num futuro melhor.

Por sinal, muitas cartas agradecem a existência do Lampião que, possivelmente, se deu pelas condições adversas de vulnerabilidade social e preconceito vividas por homossexuais naquele período. Esses leitores se deixam afetar por um conjunto de enunciados úteis à criação de um lugar para elesas no mundo, lugar este que parecia estar destinado àqueles que assumissem as homossexualidades. Não foi à toa a seleção, por parte do jornal, de cartas escritas tratando desse tema ou o abordando de maneira sutil.

Não é demais lembrar que cartas de leitor são utilizadas também em virtude da ausência de contato entre o remetente e o destinatário. Maria Lúcia Andrade lembra que essa tipologia textual atende a propósitos comunicativos: agradecer, reclamar, parabenizar, criticar. ${ }^{17}$ As cartas guardam uma proximidade particular entre o oral e o escrito, sobretudo as de caráter íntimo, a exemplo das veiculadas no Lampião. 
É o que parece ocorrer na linguagem das cartas ao remeter para uma característica estruturante na arquitetura do assumir-se: o homossexual seria triste e solitário. Ao falar de si, daria voz a tantos outros que, pela leitura, se sentiriam motivados a também se constituir como homossexuais através do exercício epistolar. Afinal, escrever para o jornal sugere se identificar com as práticas discursivas do mensário.

Desse modo, o jornal colaborava na constituição de subjetividades e era igualmente o canal que as oferecia para a leitura. Entretanto, essas cartas representavam a construção de uma identidade, a de homossexual. Esse desejo retirado do "interior do indivíduo" era deslocado do particular para o público, obedecendo à estratégia de um dispositivo que necessitava de emoções e subjetividades na sua constituição, como aponta Giorgio Agamben. ${ }^{18}$ As narrativas dessas cartas possuíam uma função genuína porque procuravam demarcar as modificações de um processo de negação para a aceitação e publicização da homossexualidade.

No fim da ditadura civil-militar, diante do par violência física e violência simbólica, representado pelos governos militares, a literatura pouco se preocupou com a expressão de emoções individuais, lembra Ana Maria Machado. ${ }^{19}$ A aceleração dos acontecimentos de tortura e repressão dificultava um tempo maior de debate sobre recursos de escrita e estilística textual, ou seja, cuidados de linguagem e elaboração romanescas atreladas a observações psicológicas, com destaque nas emoções, foi quase uma ausência.

Sentir, emocionar-se, ter uma vida afetiva podia ser uma atitude de omissão e covardia ao passo que o estado de exceção da ditadura perseguia, torturava e matava os que a ele se opunham. Assim, escrever sobre o campo emotivo numa época marcada pela repressão, censura e desaparecimento de presos políticos poderia, inclusive, soar como uma cumplicidade para com a repressão. Com a minimização do campo afetivo na literatura, "fechavam-se as comportas do emotivo, do delirante, do fantástico, do sutil, do simbólico, do onírico - qualidades que iam sendo rotuladas de femininas (ou infantis)". ${ }^{20}$ A volta dos exilados e a escrita de estilo sério e com um viés documentável colaborou com o descrédito para o estilo conotativo ou fictício. Por outro lado, alguns escritores do período usaram e abusaram das metáforas na tentativa de burlar a censura.

Ambas as cartas acima mencionadas compartilham elementos que definem aspectos de sentimentos homossexuais, enquanto a política do país vivia os efeitos da anistia, ${ }^{21}$ cuja lei foi promulgada em 28 de agosto 1979 pelo presidente João Batista Figueiredo, após ampla mobilização popular visando ao retorno de exilados políticos ou saída da prisão dos dissidentes que se opuseram ao regime.

Os fragmentos anteriormente citados estão na primeira pessoa porque se trata de uma carta particular; é apenas "um" quem escreve, ambas se destinam a um coletivo que, devido à seleção do jornal, se identifica com o conteúdo 
das cartas e dos assuntos veiculados no Lampião. Se assinaram seus nomes, os autores ultrapassavam a fronteira cultural do silêncio e do gueto e se colocam como homossexuais. Confluem, assim, duas perspectivas com relação à homossexualidade: a tentativa de narrar um sentimento e a divulgação dos receios de tornar pública a identidade sexual.

Os anseios das escritas de si nas cartas de Andrade e Penny refletem, além de um registro do eu, a constituição do próprio sujeito. $\mathrm{O}$ ato de escrever a respeito desses sentimentos relaciona-se numa performance ${ }^{22}$ identitária, uma modificação de si encenada na escrita do texto.

A mídia, ao eleger cartas com essas temáticas, acaba por funcionar como um canal de desabafos, espaço para narrar lembranças muitas vezes tristes. Nos fragmentos dessas cartas, são frequentes espaços de recordação, a fim de romper com a tristeza de outrora e buscar, através das promessas do assumir, a felicidade de lidar com as homossexualidades.

Se o Lampião representou a voz das crenças dos homossexuais, suas cartas trouxeram escritas que lutavam contra o poder, contra o silêncio, visando ao acesso à palavra e, paralelamente, à configuração de outra relação de poder: a de sugerir a seus leitores que visibilizassem a sua homossexualidade. É o que se confirma na seleção de cartas que traz esses sentimentos de insegurança e tristeza relacionados aos desejos dos seus autores, dentre eles o de não se assumir.

A seleção dessas cartas pelo Lampião estava a serviço de um dispositivo de escrita que legitimasse as negatividades de não se assumir, de ver nas homossexualidades uma prática anormal. Quando o jornal escolhia cartas da aceitação de si como homossexual, ele conferia outra ramificação ao dispositivo de confissão: superar questões oriundas do estigma das homossexualidades para daí se assumir.

Aliás, é nesse momento da história do Brasil, passagem dos anos 197080, que emergiu o dispositivo de confissão das homossexualidades. Teria sido, inclusive, por meio dos discursos propagados no Lampião, em entrevistas, artigos de opinião, cartas de leitores, dicas de livros, reportagens. Nesse sentido, a análise dessas cartas sintoniza-se com esse momento, uma vez que esboça a constituição das subjetividades homossexuais em meio a esse dispositivo. ${ }^{23}$ Inegavelmente, um elo é criado: recordação e identidade. O jornal incrementa o quadro do dispositivo de confissão das homossexualidades, ao difundir um conjunto de discursos sobre quem é o guei, quem é o homossexual. Ao tentar criar uma identidade, eles buscam introjetá-la nos seus leitores. A construção dessa identidade - o estudo das fontes deste artigo permite esclarecer - exige a superação de uma visão negativa que os homossexuais tinham de si mesmos para, finalmente, ser possível adotar a identidade de homossexual. A recordação do passado nas correspondências, quando práticas sexuais são narradas de maneira angustiada, ao mesmo tempo traz a operacionalização de 
uma dobra ${ }^{24}$ sobre si significada na aceitação da homossexualidade e aberta aos ganhos e conquistas do assumir-se.

Acredito que boa parte da edição de dezembro de 1979 esteve preocupada com esses discursos de solidão e superação do que consideravam ser a repressão sexual. O Lampião seria um amigo à distância, o retrato de que havia um outro mundo, a representação, portanto, de que era possível sonhar com lugares heterotópicos, que existem, mas o acesso seria barrado por convenções e normas sociais. ${ }^{25} \mathrm{O}$ jornal se valia, em cada edição, desde a capa, da aceitação da sexualidade, desse espaço de solidão perante os demais. Vejamos uma fotografia que constou na capa da edição em questão.

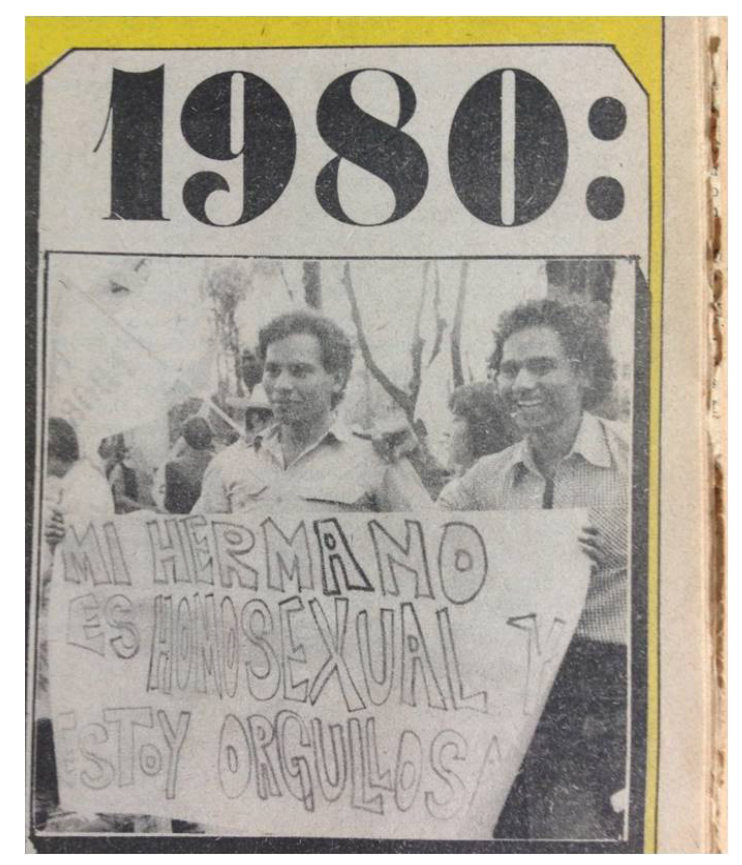

Lampião da Esquina. Foto da capa, edição 19, dezembro de 1979.

A fotografia acima é digna de atenção porque afirma um laço familiar: é o irmão de um homossexual quem segura a faixa. Ela foi produzida na Parada Gay do México, em 1979. Talvez por se tratar de uma realidade exterior, a imagem delineia bem os rostos dos rapazes e, sobretudo, ambos não se definem como homossexuais. Mesmo que um deles seja, não é possível saber qual. As imagens de homossexuais brasileiros trazidas no periódico raramente permitiam uma representação clara de quem seja, observa Jorge Caê Rodrigues:

Apesar de o jornal propor um "assumir-se", naquele 
momento ainda era muito difícil (e ainda hoje o é, aliás) as pessoas se deixarem fotografar, pois a exposição individual podia trazer problemas de ordem pessoal ao fotografado. Desta forma, em todas as reportagens sobre os encontros gays, as fotos são pequenas, as pessoas estão de costas, ou reproduzidas em alto contraste. Os meios-tons são apagados, criando uma imagem de contrastes em que não se reconhecem rostos. É claro que existiam aqueles que não tinham problemas em aparecer, mas a maioria ainda estava "no armário". O uso da máquina fotográfica nos eventos era sempre um ponto importante de discussão nos debates das organizações. ${ }^{26}$

É oportuno mostrar relações com outros discursos da época a fim de compreender os canteiros dessas cartas, as condições de sua historicidade. Em 1979, era lançado o livro Sexo e Poder, organizado por Guido Mantega. O conjunto de textos segue um debate acerca da sexualidade sob o olhar de Hebert Marcuse, notadamente pelo sucesso da obra Eros e Civilização ${ }^{27}$ na década anterior. Na apresentação do livro, Mantega comenta que a obra aparece graças ao enfraquecimento da censura sexual. Era o que se via, sobretudo, na televisão, onde "já se fala em aborto, necessidades sexuais, educação sexual na escola e outros assuntos 'apimentados'", o que, para o autor, traz uma certeza: “'a moral', 'os bons costumes', e, principalmente, os 'maus' continuam sendo uma questão de Estado, uma ameaça à segurança nacional e um risco à ordem e manutenção da família". ${ }^{28}$

Em meio a esse clima foi organizado, em São Paulo, um debate para discutir os movimentos minoritários característicos da segunda metade dos anos 1970. O debate contou com a participação dos lampiônicos, maneira como os jornalistas do Lampião eram identificados, Jean-Claude Bernadet e João Silvério Trevisan, além de Inês Castilho, jornalista do Nós, mulheres; Edélcio Mastaça, ator e diretor teatral; Raquel Moreno, militante feminista; e Cesar Augusto de Carvalho, professor de teoria política.

O debate começou com uma reflexão acerca do significado dos movimentos minoritários e dos programas de ação social. Bernadet, inclusive, pontuou o equívoco do termo 'minorias', referindo-se a negros, homossexuais e mulheres; com relação ao "homossexualismo", não se tratava de uma questão somente dos homossexuais, mas da sociedade em seu conjunto, ou seja, era um tema social e cultural. Segundo o crítico de cinema, "o próprio fato de se usar a palavra 'minoria', baseada num critério quantitativo e não num critério de processo social, já é uma maneira de isolar grupos estigmatizados da sociedade global". ${ }^{29}$

As questões do operariado e da luta de classes, que já levava como destaque o nome de Luiz Inácio Lula da Silva na região do ABC paulista, passava a ceder lugar a outros temas, notadamente ao debate sobre sexualidade e direitos 
civis, levantadas pelas 'minorias'. Inclusive a atuação homossexual no cenário nacional parece ter sido uma das últimas dentre esses grupos. Ora, antes do Lampião, havia grupos e associações tanto de feministas quanto de negros.

O tema exclusivo das homossexualidades foi debatido em março de 1979, numa mesa-redonda organizada por Flávio Aguiar, em São Paulo, com membros do grupo Somos, fundando em maio de 1978, quando se chamava Núcleo de Ação e dos Direitos dos Homossexuais, passando a usar o sugestivo palíndromo no ano seguinte. Os debatedores se apresentaram apenas com o primeiro nome, de modo a não comprometer seus empregos nem suas vidas pessoais.

Começava um debate em defesa das homossexualidades, levando em conta os malefícios do padrão heterossexual na sociedade. Emanoel, membro do Somos, assim se expressou: "um homossexual é fruto de uma relação heterossexual; então, o único padrão de sexualidade a que ele vai ter acesso é o padrão heterossexual". ${ }^{30}$

Outros questionamentos emergiram. Nessa discussão, colocava-se como o homossexual era pensado nos estereótipos sociais. Tratava-se de questionamentos de características da homossexualidade no Brasil de 1979 que colaboraram na aceitação e publicação da homossexualidade como "algo que existe dentro de mim e que de algum modo tem que aflorar e entrar em atividade", destacava Emanoel, que ainda afirmava: "na medida em que sou reprimido e não posso me expor, no momento em que há condições para eu me manifestar publicamente, evidentemente vou considerar isso uma conquista". Esse conjunto de opiniões está carregado da experiência de se assumir, da tensão entre fazê-lo ou não.

Nas configurações sociais da passagem dos anos 1970-80, assumir era, também, vencer o sentimento de culpa por estar no espaço "diferente" e "anormal" característico das homossexualidades. Em 1976, João Silvério Trevisan tentou organizar um grupo para discutir homossexualidade, mas não deu certo porque boa parte dos poucos integrantes se sentia culpada por "ser" homossexual. ${ }^{31}$

Não por acaso, o sentimento de culpa diante das homossexualidades era um das emoções vividas por homossexuais daquela época. Na mesa-redonda acima mencionada, a fala de Jorge reporta a esse sentimento: "acho que o homossexual só vai atingir uma forma total de prazer na medida em que ele eliminar seu sentimento de culpa pelo fato de ser homossexual". ${ }^{32}$

Cartas que circularam no Lampião, na mesma medida, produziam relatos a respeito do tema. Tais narrativas foram trazidas ao periódico como fragmentos de histórias de vida, podendo ser pensadas como escritas de si. As correspondências, por vezes curtas biografias, funcionavam como "o próprio corpo daquele que, transcrevendo suas leituras, delas se apropriou e fez sua a verdade delas: a escrita transforma a coisa vista ou ouvida em forças e sangue". ${ }^{33}$

Pedro de Souza estudou a confissão da homossexualidade através das 
cartas enviadas ao Somos. ${ }^{34}$ O linguista destaca dois espaços dos quais o interlocutor pode estruturar a confissão: um, a autoridade a qual se destina; dois, a confissão entendida como uma maneira de falar de si, objetivando uma afirmação coletiva.

Não por acaso, solicitavam o ocultamento do nome Somos em caso de responderem as cartas enviadas. $\mathrm{Na}$ condição de remetentes, esses homossexuais se nomeavam com pseudônimos ou ocultavam o nome no domicílio do remetente. Em carta de 1981, segundo Souza, vê-se: "quando vocês responderem esta carta, usem a sigla SOMOS-GAH, porque se a palavra Homossexual aparecer por extenso o pessoal do correio passará a me encarar de uma maneira especial". Na realidade, seu trabalho deixa claro, na escrita dessa carta, que "o remetente aceita a proposta de assumir, mas sob a condição do sigilo". 35

Há semelhanças entre a escrita de cartas enviadas aos Somos e ao Lampião. Elas falavam de si, dos traumas, das dores, das alegrias, dos sentimentos, porque, provavelmente, não havia, no cotidiano, um espaço para essa prática. A escrita das cartas afirma uma subjetividade construída em torno da confissão e mostra a dificuldade de falar de si, a não ser em certos casos, por meio da escrita.

No conjunto das Cartas na mesa houve relatos de pessoas que não compravam o jornal por medo de serem reconhecidas como homossexuais ou, simplesmente, por terem receio de se assumir. Foi o caso de Carlos N., de Curitiba:

Lampião, cordiais saudações. Escrevo-lhe para expressar minha satisfação em ter descoberto a existência desse jornal. Não o conhecia, fiquei muito feliz pelas reportagens do $n^{\circ} 13$ - junho de 1979. Agora, o que eu não sei é se o jornal é exclusivamente para os viados e para as lésbicas. Fiquei feliz, porque sou guei.

Só não posso assinar o jornal porque ainda não assumi. Isso, porque correria o risco de ser descoberto pelas pessoas daqui de casa, que são muito preconceituosas e cheias de tabus. E ainda por cima, pertenço a uma congregação religiosa, daí a minha situação crítica. Sou muito tímido, por isso não tenho muitos amigos. Os poucos que tenho não sabem que sou viado. E se souberem, a amizade morre, pois Curitiba é uma cidade provinciana. Estou the escrevendo para the pedir ajuda. Se fosse possível me mandar por carta os endereços de algumas pessoas que são homossexuais ativas ou passivas para que eu possa ter com quem me abrir. Eu disse que não assino o jornal por precaução, mas agora passarei a comprá-lo sempre nas bancas. É menos arriscado. Se souber do endereço por carta de algumas pessoas daqui 
de Curitiba e me enviar, muito grato ficarei. ${ }^{36}$

A expressão "sou guei” parece um grito ecoando em uma época em que os homossexuais eram tolhidos pela falta de direitos, de leis que assegurassem prerrogativas ao seu favor; um grito de um momento na história do Brasil, marcado por um profundo preconceito contra esses indivíduos, embora tal situação estivesse passando por modificações, conforme se percebe nos discursos veiculados no Lampião.

Os editores do Lampião sabiam perceber o seu tempo, pois investiram numa série de discursos objetivando esclarecer os preconceitos contra homossexuais, mas também contra as mulheres e os negros. Esses dois últimos grupos sociais tiveram importância significativa e estratégica em toda a vida do mensário, ocuparam capas, ${ }^{37}$ grandes reportagens na tentativa de inserir a questão homossexual no conjunto dos debates sobre as minorias.

"Sou guei", na carta anterior, não é a negação da heterossexualidade, mas o desejo de se incluir, de fazer parte, de somar-se a um conjunto de discursos sobre as homossexualidades divulgados no jornal. O debate em torno da anistia, a volta de exilados políticos, o abrandamento da censura desenhavam um cenário a ser ocupado por novas questões, inclusive aquelas que, em certo lugar do passado, foram construídas como indignas de importância e atenção social.

Carlos, ao identificar-se, desejava ser aceito. Porém, ele não compra o jornal com frequência. Assinar o jornal, na escrita de Carlos, é uma atitude de assumir. Ter uma correspondência mensal chegando em casa poderia despertar atenção, olhares de curiosidade, bisbilhotices do quarto do rapaz. Há aí um medo frequente: os receios de a família descobrir. Receios percebidos pelo mensário e trabalhados na tentativa de encorajar os homossexuais a entrarem em ação por meio de se autoafirmarem homossexuais. Assinar e assumir são dois verbos que se casam na publicização da homossexualidade. Eles caminham juntos. Ainda que o Lampião chegasse em envelope lacrado e disfarçado sua simples leitura se configura como ato de assumir a si mesmo, para si e para a equipe do jornal, que, como destacou Bandeira, ${ }^{38}$ julgava interessante essa campanha também devido ao número de vendas do jornal.

Parece que uma linha de sofrimento atravessa a carta de Carlos. Os poucos amigos poderiam se afastar ao descobrir a homossexualidade, fato que fazia com que Carlos certamente se performatizasse com características heterossexuais a fim de não despertar dúvidas. A heterossexualidade precisava residir num espaço sólido, firme e público. Do contrário, as consequências podiam ser desagradáveis. Carlos esperava que sua solidão fosse amenizada por meio de correspondências trocadas com os/as demais leitores/as. Por isso fizera esse pedido ao jornal. Não se solicitava apenas um endereço, procurava um amigo, ainda que distante, alguém que se fizesse presente por meio da escritura, quando os olhos percorressem frases de ajuda, de colaboração, de atenção, ou, 
simplesmente, de escuta. Mas, talvez, também desejasse se libertar e colocar em prática seus desejos, inventar novos usos para os corpos.

Parte desses leitores possivelmente queria contatos com outros parceiros, numa mesma cidade ou numa localidade próxima, para relações sexuais. A presença, no Lampião, da coluna Bixórdia, permite essa análise, pois se tratava de uma coluna na qual os leitores se descreviam fisicamente, deixando seus atributos e o que lhes agradava na personalidade do outro.

Esse turbilhão de emoções só ocorre porque, por meio da seção Cartas na Mesa, o Lampião conseguiu dar voz e expressar o que leitores/as de diversos locais do país consideravam importante. Essa seção do jornal foi canal de emoções e sentimentos, mas, igualmente, da possibilidade de colocar em discussão as homossexualidades por meio das várias biografias de vida que vinham aos pedaços nessas correspondências. Pouco a pouco, percebe-se que as cartas são o espaço, por excelência, da recepção das ideias do assumir veiculadas pelo jornal. Observe:

É com muita ansiedade e tensão que lhes escrevo. Sou alguém levado pela curiosidade e necessidade de me conhecer como ser humano, que, em junho/80 me tornei um assinante do Lampião. Tenho a lhes dizer que só ganhei alegrias, desde quando os descobri, e daí passei a me liberar e ainda estou em transição de mudança. Tudo que vocês possam imaginar em matéria de ignorância e desrespeito ao ser humano homossexual por aqui existe. Foi preciso eu pensar muito antes de assinar Lampião e tenho andado amedrontado pois minha cabeça mudou muito em relação à sociedade e o perigo por aqui é ser marginalizado. A gente é pobre, vive com a família reprimido de todos os lados; não foi à toa que já fiquei dois meses internado em um sanatório de doentes mentais aqui. Foi terrível, já faz um ano e meio, mas as marcas deixadas e enraizadas dentro de mim estão muito vivas.

Olha gente, nem sei se deveria escrever coisas assim, mostrando uma inocência e ingenuidade que talvez possa até me prejudicar, porém, confio nesse jornal e espero estar sendo correto e julgá-los positivamente. Queria sugerir ao jornal que publicasse matérias nos informando e esclarecendo sobre o trabalhador homossexual. Partindo de mim, tenho a dizer que o principal obstáculo que me impede de tornar-me declarado e assumido perante a sociedade é a questão do mercado de trabalho. Eu sobrevivo dependente do trabalho, não sou mão de obra qualificada e meu emprego atual posso dizer ser meu cativeiro. Dependente dele para o arroz com feijão de todo dia, fico sujeito a aceitar as 
regras machistas e moralistas que praticamente podam toda expressão liberatória que ora nasce dentro de mim.

Lendo Lampião, meu interior se libertou, mas ficou preso ao mundo que me cerca, condenado à gaiola repressora da sociedade. Sou como um pássaro que nasceu cativo; de repente lhe dão a liberdade e ele, sem conhecer o mundo e as leis de sobrevivência da natureza, estaria condenado à morte.

Sou uma pessoa medrosa, porém admiro os corajosos como os redatores do Lampião, como os homossexuais que têm a liberdade de se amarem e não se incomodam com a marginalização que lhes cai às costas, porque são fortes e sábios, conquistaram sua independência financeira e por isso não devem satisfação a ninguém. Infelizmente eu devo satisfação ao meu local de trabalho, às pessoas que convivem diariamente comigo, que, se soubessem da minha realidade me atirariam ao lixo. (...).

(...). Admiro este jornal, leio escondido de todos que me cercam, e às vezes me sinto um idiota por ser diferente de todos que me cercam. Há oito meses atrás eu vivia me violentando para ser igual a eles, mas agora, por esse tempo todo que li esse jornal criei coragem de me olhar como sou e me aceitar diferente do resto, e a criar esperança de num futuro próximo sair à luz do mundo como muitos homossexuais já fizeram. Fica aqui minha admiração pelo trabalho de vocês. Irei sempre que puder divulgar esse jornal porque vocês falam pela minha garganta muda, e que está louca para gritar mas não pode. ${ }^{39}$

Em primeiro lugar, há o encontro com mais um caso do assumir-se e da impossibilidade de fazê-lo. O assumir, no caso de L.P., se estabelece com o corpo. Acima, tem-se a escrita de uma experiência de emoções protagonizadas por um homossexual no começo dos anos 1980.

Embora a recordação de momentos difíceis da vida de L.P. venha com doses de tristeza, é justamente daí que advém a razão da escolha da sua carta. A partir de mais essa carta, vemos como uma sociedade se estrutura por meio dos discursos que a atravessam. Mas uma escrita de si é igualmente permitida devido ao contato com um mundo de textos que irão ressignificar ideias e noções acerca das homossexualidades.

A produção do jornal preenche um local jamais pensado por nenhum periódico gay precedente. Eles, os editores, parecem tocar em um assunto estruturante da subjetividade homossexual: romper com o estigma da sociedade. A história de L.P. é uma narrativa de modificação da vida, é um indício de alguém que modifica a si mesmo pelo exercício da escritura. 
É com a escrita que L.P. pode expressar a alegria de viver influenciado por seu contato com o jornal. O conjunto de textos do Lampião, ao falar e abordar criticamente uma realidade pouco conhecida, colaborou na modificação dos modos de atuação homossexual. L.P. é um leitor que viveu um movimento de transformar a si mesmo, ${ }^{40}$ ele se modifica desde junho de 1980 , ultrapassa a si próprio para criar um outro L.P. - "meu interior me libertou".

Mesmo "preso ao mundo que me cerca, condenado à gaiola repressora da sociedade", ele pode criar linhas de fuga, permitir inventar a si mesmo recriando os conceitos de si para descrever a noção de homossexualidade. Ele se elabora, efetua rupturas consigo mesmo por meio do Lampião.

Esse recriar ocorre quando "passei a me libertar e ainda estou em transição de mudança". Embora L.P. integre a rede do dispositivo de confissão da homossexualidade, ele rompeu com o desejo de ser igual aos heterossexuais.

Entende-se, na leitura da carta, as razões desse esforço: ele foi internado para ser curado, tornou-se o estranho da família e, como se não bastasse, foi fisgado nas técnicas da biopolítica de regular e corrigir os desviados sexualmente. ${ }^{41}$ O espaço de tanto sofrimento é o interior do estado de São Paulo, cidade de Amparo. No mesmo estado, lá na capital, grupos voltados à mobilização dos homossexuais organizavam congressos e mesas-redondas, espaço onde parte do Lampião ganhava existência.

Com L.P., confirmamos que as condições para a prática da homossexualidade deveriam ser menos fáceis em regiões interioranas. Por isso, aqui, acolá, cartas pediam informações sobre pontos de sociabilidade gay nas capitais.

A pedra angular a modificar a trajetória da sua existência é barrada pela questão profissional: "o principal obstáculo que me impede de tornar-me declarado e assumido perante a sociedade é a questão do mercado de trabalho". Nesse ambiente, "fico sujeito a aceitar as regras machistas e moralistas que praticamente podam toda a expressão libertária que ora nasce dentro de mim".

Configura-se como um dispositivo se efetiva na linguagem por meio de práticas sociais. O que essas cartas permitem ler é uma modificação de si, a reformulação de uma subjetividade homossexual no fim dos anos 1970 que passava a tomar como categoria fundamental o assumir a homossexualidade.

Por fim, as cartas escolhidas para constar no Lampião passavam por uma seleção estratégica que somava os objetivos e pressupostos do assumir-se homossexual, um dos principais objetivos do jornal. Divulgá-las era uma maneira de comprovar as ideias do periódico que circulava pelo país, e como bem vimos, modificando e modelando os sujeitos leitores que foram reconstruindo processos de subjetivações em torno do imperativo do assumirse. Portanto, a seleção dessas cartas em detrimento de várias outras recebidas na redação, confirma que a ideia do dispositivo de assumir a sexualidade emergia com força no fim dos anos 1970, na história do Brasil, a partir do jornal Lampião da Esquina. 


\section{NOTAS}

1 L. M. C. Cartas que vieram de longe. Lampião da Esquina. Rio de Janeiro, agosto de 1978, p. 15.

2 Bixórdia. Lampião da Esquina. Rio de Janeiro: outubro de 1978, p. 12.

3 Idem.

4 FRY, Peter e MacRAE, Edward. O que é homossexualidade? São Paulo: Civilização Brasileira, 1985.

5 RODRIGUES, Jorge Caê. Um Lampião iluminando esquinas escuras da Ditadura. In: GREEN, James N.; QUINALHA, Renan (Orgs.). Ditadura e homossexualidades: Repressão, resistência e a busca da verdade. São Carlos: UFSCAR, 2014.

6 Lampião da Esquina. Rio de Janeiro, agosto de 1978.

7 BANDEIRA, Márcio Leopoldo Gomes. 2006. Será que ele é? Sobre quando o Lampião colocou as Cartas na Mesa. Dissertação (Mestrado em História) - Pontifícia Universidade Católica de São Paulo, São Paulo. Disponível em: http://www.sapientia.pucsp.br/tde busca/ arquivo.php?codArquivo=3067. Acesso em: $01 \mathrm{dez} .2014$.

8 GREEN, James. Beyond Carnival: Male Homosexuality in Twentieth-Century Brazil. Chicago: The University of Chicago Press, 1999.

9 Idem, Ibidem.

10 FACCHINI, Regina. Sopa de letrinhas?: movimento homossexual e produção de identidades coletivas nos anos 1990. Rio de Janeiro: Garamond, 2005.

11 SIMÕES JÚNIOR, Almerindo Cardoso. 2006. '...E havia um lampião na esquina' Memórias, identidades e discursos homossexuais no Brasil do fim da ditadura (1978-1980). Dissertação (Mestrado) - Programa de Pós-Graduação em Memória Social, UNIRIO, Rio de Janeiro.

12 SILVA, Claudio Roberto. 1999. Reinventando o sonho: história oral de vida política e homossexualidade no Brasil Contemporâneo. Dissertação (Mestrado) - Programa de PósGraduação em História Social, USP, São Paulo.

13 ALBUQUERQUE JÚNIOR, Durval Muniz de; CEBALLOS, Rodrigo. Trilhas urbanas, armadilhas humanas: a construção de territórios de prazer e de dos(?) na vivência da homossexualidade masculina no Nordeste brasileiro dos anos 1970 e 1980. In: SCHPUN, Mônica Raissa. Masculinidades. São Paulo: Boitempo; Santa Cruz do Sul, EDUNISC, 2004.

14 ANDRADE, R. Lampião da Esquina. Rio de Janeiro, dezembro de 1979, p. 18.

15 PENNY. Lampião da Esquina. Rio de Janeiro, dezembro de 1979, p. 19.

16 FOUCAULT, Michel. História da sexualidade I: A vontade de saber. São Paulo: Graal, 2012.

17 ANDRADE, Maria Lúcia da Cunha Victório de Oliveira. Cartas do leitor: interatividade na correspondência publicada em jornais. Revista da ANPOLL, v. 25, p. 137-165, 2008.

18 AGAMBEN, Giorgio. O que éo contemporâneo? E outros ensaios. Chapecó: Argos, 2009.

19 MACHADO, Ana Maria. Op. Cit., p. 83.

20 Idem, Ibidem, p. 83. 
21 TELES, Janaína de Almeida. As disputas em torno da interpretação da lei de anistia no Brasil. Ideias, UNICAMP, v. 1, p. 71-93, 2010.

22 BUTLER, Judith. Atos corporais subversivos. In: . Problemas de gênero: feminismo e subversão da identidade. Rio de Janeiro: Civilização Brasileira, 2010.

23 SOUTO MAIOR JR, Paulo R. 2015. Assumir-se ou não assumir-se?: O Lampião da Esquina e as homossexualidades no Brasil (1978-1981). Dissertação (Mestrado) - Programa de Pós-Graduação em História, Universidade Federal de Pernambuco, Recife.

24 De acordo com Gilles Deleuze, a dobra está relacionada com o que Foucault descobriu nos gregos antigos no que se refere a uma arte de viver (subjetivação). A dobra é a capacidade de subjetivação, ou seja, "curvando sobre si a força, colocando a força numa relação consigo mesmo, os gregos inventam a subjetivação. Não é mais o domínio das regras codificadas do saber (relação entre as formas), nem o das regras coercitivas do poder (relação da força com outras forças). São regras de modo algum facultativas (relação a si): o melhor será aquele que exercer um poder sobre si mesmo. Os gregos inventam o modo de existência estético. É isso a subjetivação: dar uma curvatura à linha, fazer com que ela retorne sobre si mesma, ou que a força afete a si mesma. Teremos, então, os meios de viver o que de outra maneira seria invivível. O que Foucault diz é que só podemos evitar a morte e a loucura se fizermos da existência um 'modo', uma 'arte'” (p. 145). Para mais informações, consulte: DELEUZE, Gilles. Conversações. São Paulo: Editora 34, 2010.

25 FOUCAULT, Michel. O corpo utópico: as heterotopias. São Paulo: n-1 edições, 2013.

26 RODRIGUES, Jorge Caê. Impressões de identidade: um olhar sobre a imprensa gay no Brasil. Niterói: UFF, 2010. p. 89.

27 MARCUSE, Herbert. Eros e civilização. Rio de Janeiro: Jorge Zahar, 1972.

28 MANTEGA, Guido (Org.). Sexo e poder. São Paulo: Círculo do livro, 1979. p. 5.

29 Idem, Ibidem, p. 122.

30 Idem, Ibidem, p. 135.

31 TREVISAN, João Silvério. Devassos no paraíso: a homossexualidade no Brasil, da colônia à atualidade. São Paulo: Record, 2007.

32 Idem, Ibidem, p. 142.

33 FOUCAULT, Michel (2004) apud KLINGER, Diane Irene. Escritas de si, escritas do outro: o retorno do autor e a virada etnográfica. Rio de Janeiro: 7 Letras, 2007. p. 28.

34 SOUZA, Pedro de. Confidências das carnes: o público e o privado na enunciação da sexualidade. Campinas: UNICAMP, 1997.

35 Idem, Ibidem, p. 47.

36 N. Carlos. Lampião da Esquina. Rio de Janeiro, agosto de 1979, p. 18.

37 Negros: qual é o lugar deles? Lampião da Esquina, n. 15, Rio de Janeiro, agosto de 1979. Amor entre mulheres. Lampião da Esquina, n. 12, Rio de Janeiro, maio de 1979.

38 BANDEIRA, Márcio Leopoldo Gomes. Op. Cit.

39 L.P. Amparo-SP. Lampião da esquina. Rio de Janeiro, março de 1981, p. 2.

40 Sobre os processos de subjetivação, ver: DELEUZE, Gilles. Empirismo e subjetividade: ensaio sobre a natureza humana segundo Hume. São Paulo: Editora 34, 2012. 
41 AGRA DO Ó, Alarcon. Biopolíticas e Velhice. Revista Espaço Acadêmico, UEM, v. 117, p. 14-22, 2011.

Artigo recebido em julho de 2016. Aceito em setembro de 2016. 